\section{Research Square}

\title{
From prison induction into the sentence. Analysing prison officer support and assistance in a small island state.
}

Michela Scalpello ( $\square$ michela.scalpello@port.ac.uk)

University of Portsmouth https://orcid.org/0000-0002-1259-5166

\section{Research Article}

Keywords: Prison, prison officer, support, rehabilitation, prison programmes, induction

Posted Date: July 6th, 2021

DOl: https://doi.org/10.21203/rs.3.rs-624357/v1

License: (c) (i) This work is licensed under a Creative Commons Attribution 4.0 International License.

Read Full License 


\section{Abstract}

This paper sheds light on male Maltese prisoners and their perception of help and support when incarcerated at Corradino Correctional Facility (CCF), Malta's only prison. Through thematic analysis, the viewpoints, thoughts, and feelings of 39 males were explored. This was done in relation to programmes aimed to help prisoners in their desistance journey. Thought-provokingly, many prisoners spoke to the lack of support they felt within this prison. Even though there was only one question in the interview schedule which focused on how the prisoners felt in terms of support, this talk of support systems, or lack thereof, featured in many instances, frequently enough to warrant an analysis of its own. Themes emerging from this paper suggest that relationships between prisoners and prison officers are not supportive to any rehabilitative ideal. Prisoners speak of the lack of induction, information, and support, and of being mocked when requesting information or assistance. They state that support is conditional on who they knew, not withholding direct references to corruption, and even though some officers do attempt to provide proper care, they are limited by the institution, and by the colonial mentality of such a small island state.

\section{Introduction}

When faced with a prison sentence, the transition from freedom to captivity is an extremely desolate time (Sykes, 1958/2007), where a new prisoner must adjust to a new situation. This new world, a "total institution" (Goffman, 1961, p. 11), is an incomprehensively different world from the one just left behind (Farley \& Hopkins, 2017) since prisons are largely portrayed as the ultimate emblem of immobility. Sykes $(1958 / 2007)$ asserts that an awkward balance between solidarity and alienation is present within a prison setting, with support being a crucial element for survival.

As the first, and most frequent, point of contact, prison officers are at the centre of any prison regime and therefore prison life (Liebling, 2011), to the extent that they are often synonymous with a prison and its environment (Maycock et al., 2020). They are often erroneously and solely linked to the practical roles of their job (Arnold, 2016), for example unlocking prisoners, checking locks, bolts, and bars (Scott, 2006), perhaps because they are at the frontline for transmitting penal culture and prison policy (Steiner \& Wooldredge, 2018). However, prison staff are also vital for support for rehabilitation (Akoensi \& Tankebe, 2020). Therefore, relationships between prisoners and prison staff should transmit auras of both power and authority, yet also trust and respect (Liebling et al., 1999), since they act as a 'strength' contributing to desistance (Maruna \& LeBel, 2002), essentially playing a significant role in reducing the pains of imprisonment (Tait, 2012). Indeed, Braggins and Talbot (2005) highlight how prison officers identify three unique functions to their role: an enforcer, a carer and a reformer. They stress that it was usually when under pressure that officers resorted to the default 'enforcement mode'. At other times, they were eager to partake in the caring and reformative roles. Even though the idea of 'care' is not often correlated with prisons, it is a central concept to the staff-prisoner relationship (Tait, 2011). Care is personalised and approached at diverse angles and intensities by different individuals, at a range from what she calls "true carers" (confident and secure) to "damaged" (uncaring and disinterested) officers (Tait, 2011). 
Despite these differences with the 'measured' level of care, staff and prisoners share physical and social space daily, and familiarities are unknowingly developed. Banter and acts of concern and kindness (Sparks et.al. 1996) are more frequent than the tough and action-oriented personas within the prison environment would likely reveal (Crawley, 2004). Indeed, Liebling et. al (2011) show how helping prisoners added meaning and satisfaction to a prison officer's job. Furthermore, research has also clearly indicated that the more respectful and humane prison staff are, the less misconduct is seen within the prison (Reisi \& Mesko, 2009; Sparks et. al., 1996), since the notion of security is one which presumably frees the individual from worry about their own personal safety, and instead gives them the opportunity to selfactualise (Elliot, 2007).

Therefore, prisoner-staff interactions hold a lot of weight in positive prison experiences. Many factors contribute to this idea of positivity, including fair, equal, and humane treatment, positive and supportive environments, a sense of security and frequent interactions (Elisha et. al., 2017). To relay such ambience of trust, respect, and fair treatment, a principal characteristic for prison officers to portray is support towards prisoners, an essential element to rehabilitation (Harvey, 2007; Liebling et al., 2005).

Unfortunately, it has been observed that male prison staff feel great discomfort in performing perceived feminine, and servile, jobs (Tracy, 2005), and care and support have been socially constructed to be perceived as feminine traits. Prisons are seen as highly masculine environments (Earle, 2018), where "the traditional female qualities of nurturance, sensitivity, and understanding" (Zimmer, 1986, p. 3) are unwelcome. Perhaps partly due to these various gender stereotypes, prison staff culture has often been interpreted rather negatively - characterised by insularity, group solidarity, pragmatism, suspiciousness, cynicism, conservatism, machismo along with distance from senior management (van Zyl Smit \& Snacken, 2009). The so-called "guard subculture" promotes group loyalty, a feat which is strictly opposing of any 'other', in this case, prisoners (Worley, et. al. 2021).

Within a small island state, Malta, this negative notion revolving around prison-staff culture, along with the 'us' and 'them' mentality is profound. Within the present study prisoners interviewed felt that the prison, and all that it stands for, offered them no support. The consensus was that 'rather than giving you help, [prison staff] break you'(Henry). Reasons for this lack of support varied, but prisoners suggested there was no attempt at rehabilitation and resettlement at the prison with others adding that this was contrary to the prison's official name, at time of interviewing being Corradino Correctional Facility.

This paper focuses on a specific characteristic, and perhaps role, prison officers should be adhering to daily in line with rehabilitative ideals- support. The paper is based on qualitative interviews with 39 prisoners in Malta's only prison, Correctional Services Agency (called by its previous name Corradino Correctional Facility at the time of interviewing). The full study was based around prison programmes available at the prison, in relation to rehabilitation and resettlement. 


\subsection{Small island state prison: Malta}

Malta is the tenth smallest country in the world (World Population Review, 2021), and one of the six European microstates. Within its 124 square miles of land area, by the end of 2020 Malta had a population of 441,543 (Worldometer n.d.), making it a small state. In 1814 Malta was taken over as a Crown Colony under British rule yet became a Republic in 1974. Having its own territory, people and government now meant that Malta had become a sovereign small state (Fowler \& Bunck, 1996).

Presently, Malta runs on a mixed legal system, having roots in Civil, (continental) Law, with ingrained aspects of British Common Law (Attard, 2013). Similarly, the Maltese language is a fascinating muddle of languages and dialects, incorporating language from the Semitic family, Latin, Sicilian, and English. This illustrates that even though Malta did stay afloat, the price to pay has been strategies which are accommodating, since they revolved around the exploitation of any niche, or previously enacted aspects to law and culture. However, it has always adopted and adapted aspects of foreign powers and cultures and made them its own, playing strategy games with stronger and richer international allies. Through some not-so-legal enterprises, corruption and high costs for the people, Malta's economy has survived (Engel, 2018).

This short geo-historical preamble leads to the heart of this paper. Such as small states are not singled out by policy makers on their differences to other larger states (Baldacchino, 2012), so too is the small Maltese prison not allotted a vital spot within penological research. Rehabilitation and resettlement on the Maltese Islands are both very under-researched areas, the relationship between prison staff and prisoners in terms of rehabilitation even more so. Therefore, the analysis of such a vital, and unexpected, theme will be beneficial in terms of rehabilitation and resettlement, and as an addition to the largely absent penological aspect of the Maltese prison service. Research within CCF is not only near impossible to conduct but is actively discouraged - at times plain-out refused - by those who hold power. They would rather keep the status quo.

Physically cut off from the rest of Europe by the Mediterranean Sea, Malta has always lagged a few years behind other more advanced countries. Its borders have oftentimes not exclusively served as physical boundaries, but also as barriers to movement and changes in administrative practices, public and private sector actions, as well as procedures of control (Lemaire, 2015). Whilst parts of Europe has been moving towards a rehabilitative ideal (Martufi, 2018), Maltese authorities have hand-picked an ex-army personnel as the new prison director. With a notice blatantly stating that 'it's our job to teach fear' which was visible for all inside the prison (Delia, 2021), his tactics are not concealed. Such instances illustrate how Malta's operational timeline is stuck in the 1970s, a time which brought a decline in faith in rehabilitation due the new phenomena of 'prisoner warehousing'. This punitive crime-control model, and the philosophies revolving around them led to a decrease in sociological research in prisons, worldwide (Jewkes, 2014). However, Malta takes it a step further. Any kind of prison research is absent on the island, meaning that 
for decades on end the prison has managed to evade any obligation which rates their success on actual rehabilitation (Bastow, 2014), and humane conditions.

Secrecy within Malta is profound, aggravated only within the prison setting. Such a lack of transparency is very evident in cases of deaths in custody. Between June 2018 and December 2020 there have been eleven deaths (at a rate of 5 prisoners per 1,000), yet no details are provided under the "confidential in nature" guise. It was only affirmed that "the absolute majority of them - about $75 \%$ - were due to natural causes" (Calleja, 2020), a statement which leaves much to be desired in terms of the operations of the Maltese Criminal Justice System. When the age range of most deaths being in the 25-50 age bracket, the 'natural causes' explanation does not hold much weight. A discussion of transparency, or better lack of, in Malta is not the scope of this paper, however it does bring to the fore the utmost importance of the prison officer. Their role demands the protection of life, safety, and security; therefore, they are at the front of preventing unnatural deaths (Ricciardelli et. al, 2020), through promoting wellbeing and support. However, if all deaths are deemed to be 'natural' then prison officers will be untrained in such aspects, where mental health is not seen as a priority and a feature in a higher risk of suicide. Within the same argument, with no official record of trends on the island, added to harmful punitive mentalities, such as the conclusive and deterministic viewpoint that crime on the island is intergenerational (e.g., Formosa Pace, 2014), the prison will have no space to focus on the role of prison staff to facilitate rehabilitation and resettlement.

Malta has only one prison, Corradino Correctional Facility (CCF) at time of interviewing. At present, the principal goals of CCF allegedly revolve around custody, safety, health, rehabilitation, and resettlement (Home Affairs, 2020). To achieve this, CCF's motto states that the prison is suavis ex aspero, which translates to 'firm but gentle'. Despite its architecture following a British panopticon ideology, CCF got its name from the American usage of the phrase correction rather than prison. However, prisoners are still referred as prisoners and to the public the facility is referred to as a prison, which shows that some aspects of British culture have been cherry picked, with security and "populist punitiveness" (Bottoms, 1995, p. 40) taking precedence. However, the current study concludes that the UK's 'rehabilitative culture', where the relationship between prison staff and prisoners is the foundation of successful desistance (Mann \& Fitzalan Howard, 2018), has not reached the island's prison.

\section{Current Study. Assistance To 'make Good' As Perceived By Prisoners.}

This paper emerged from a bigger project, which explored rehabilitation and resettlement at CCF through in-depth interviews with 39 prisoners. The rationale was that, keeping in mind other factors which directly affect the recidivism rate such as crime opportunities (Clark, 2012), drug problems (Pierce et. al., 2017) and peer pressure (Maruna, 2001), recidivism rates are also reflected in the rehabilitation programs that are in place at a prison. The hypothesis was that the less successful a program, the likelier it is that an exoffender will re-offend. Data from interviews with prisoners showed both generalised passivity and a sensitivity to the negative impact of custody that left them feeling that much more disable rather than enabled. There was the primary pain of imprisonment caused by the sentence imposed, together with 
secondary punishment on the prisoner's family and then tertiary punishment where the prisoner's awareness of his (self-inflicted) predicament and lack of options and support, made him that much less able to think positively about engagement with the rehabilitative process. Looking at the prison population at CCF, which has been steadily increasing from 584 in December 2010 to 745 in December 2019 (Formosa, 2021), something is not working. The total capacity of the prison is 878 (World Prison Brief, 2021), therefore there is a growing inherent risk for over-crowding.

The theme of support was so strong it warranted an analysis of its own. Within the open-ended interview schedules, only one question specifically asked prisoners about the help and support they are offered by the prison and prison staff. However, this theme was constantly emphasised during interviews, mostly asserting a lack of support and assistance.

Throughout this article, the definition of 'support' provided by Toch (1977) will be adhered to. He defined support as any concern revolving around reliable and tangible assistance from any individual or setting, including services that facilitate self-advancement and self-improvement.

\section{Method}

For this study, a qualitative methodology is adopted using a semi-structured interview with prisoners. These interviews were held within CCF. A constructivist paradigm (Morris, 2006) has been loosely employed since this research welcomes the philosophy that individuals construct their own meaning and understanding of the world through experience and reflection. Therefore, this study analysed the subjective viewpoints from prisoners. In line with this philosophical paradigm, the data collected from respondents hold as much weight as any literature in the area (Morris, 2006).

\subsection{Data collection 3.1.1 Ethics}

Primary data was collected through semi-structured interviews with 39 prisoners housed within CCF. Prior to gaining entry to $\mathrm{CCF}$, permissions needed to be granted from the then director of prison, correctional manager, the permanent secretary for the Maltese Ministry for Home Affairs and National Security, as well as the University of Malta's Research Ethics Committee. During the data collection process, all prisoners were briefed and if they chose to participate a consent form was given. This was explained verbally, and they were given time to read through. If they were happy to proceed, they signed it and a copy was kept under lock and key. Throughout the whole study, pseudonyms were used, and no recordings, voice or otherwise, were taken. Furthermore, at no time were any CCF officials present in any interview, or privy to any of the researcher's notes.

\subsubsection{Interviews}


The interview process followed a semi-structured format and was conducted by the author in Maltese, with quotations translated to English by the author. Questions predetermined through the interview schedule were accompanied by follow-up questions to get more focused, in-depth responses, as well as to explore additional themes. By using semi-structured interviews, the research gave the prisoners the opportunity to be flexible and spontaneous in their replies. This generated the real symbolic value (Stevens, 2013) which resulted in the theme of support, or lack of.

\subsubsection{Sample}

This study had 39 male convicted respondents held at CCF. Participation criteria included a prison sentence of between 1 and 4 years. Their offence was not taken into consideration in any way, and no prisoner was included or excluded on account of their index offense. This sample criteria were established because it was vital for the study that prisoners had a good recollection of their induction process, but also be able to be able to attend any education or other prison programmes in preparation to their release. Therefore, the sentence had to be long enough for prisoners to be eligible for educational programmes, yet short enough for them to be preparing for release. On this reasoning, a sentence length of 1 to 4 years was established.

At the time of data collection, the total number of inmates at CCF was 587. Out of those, around $131 \mathrm{fit}$ the criteria, and 39 were recruited as participants. This provided a sample of $30 \%$ of those eligible.

The study used a convenience and snowball sampling since all those within the given criteria who are willing to participate, were interviewed. Participants were mainly recruited through word-of-mouth. The researcher was located within a safe space within the prison, usually the psychologists' room, and officers would ask prisoners within their wing if they would like to participate. If they did want to participate, then they could walk to the location. No officer was ever present during the interview process.

\subsection{Thematic Analysis}

Due to its theoretical freedom, thematic analysis was the primary method of analysis. It allows for rich and detailed data (Braun \& Clarke, 2015) which acknowledges the complexity of prison research. Data was analysed in a semi-inductive manner where themes established are derived directly from raw data. After each set of interviews was concluded, all data was thematically coded and analysed. Through this method, literature is used solely to enhance any empirical data, rather than seek to restrict it. Through this method, the theme of support was analysed in depth.

The themes established for this study are illustrated in Table 1 below: 
Table 1

Summary of Superordinate and Subordinate Themes

\begin{tabular}{|ll|}
\hline Superordinate themes & Subordinate themes \\
\hline Running of the prison & No information provided \\
\hline 'The green book' & No induction \\
\hline Reluctance to approach officers & Not helpful \\
\hline & Not mentioned \\
\hline Counterproductive \\
\hline Positive aspects & No help \\
\hline Indifference \\
\hline Understanding officers & Some officers try \\
\hline Dependant on mood \\
\hline L-antiki (the old ones) \\
\hline Il-godda (the new ones) \\
\hline 'just a job' \\
\hline Lorruption
\end{tabular}

\section{Results}

Within Malta's prison, respondents housed at CCF did not view prison staff as being supportive. This bleak narrative seemed to take root from their induction into prison, throughout their sentence. Respondents claimed that no information about how the prison is run in terms of rules or regimes were provided to them at any time during their sentence to date. As explained by Mark and Martin:

Mark: You enter the door, a search is done, you are taken upstairs, written into the system, you go back downstairs, and you are told in which division you're going to be put in. You are thrown in there and that is it. You are locked in the cell and at some point, a doctor would visit - because one doctor for 600 people is not always available. He is on call. And does not even understand Maltese! 
Martin: Nobody tells you nothing, what's right, what's wrong. Not even, for example, when the visits are, when my wife can come visit, my parents... what I can have in here, what I cannot. They'll only tell you when their back is against the wall. It's like having a dog in a kennel home all on his own.

Being sentenced to prison comes as a shock to many individuals, even if that court outcome had been expected. Thus, it is not alarming that studies have found that mental health problems peak at entry (Dean and Korobanova, 2017), yet these aspects are not taken into consideration at CCF. Prisoners mentioned having their photo taken, a search conducted, and handing over of personal property, all aspects of 'mortification', a heightened sense of loss of agency (Goffman, 1961). This is the beginning to another process of role stripping prisoners mention during the interview, where they reveal that they feel that they are just a number. These problems are aggravated when new intakes are not provided with any basic prison information, for example the regimes and any rules and regulations. When the necessary information and support is not provided to new inmates, their level of adjustment into the prison environment would not be at a healthy level, resulting in weaker chances at rehabilitation (Fedock, 2017).

The UN's 1955 Standard Minimum Rules for the Treatment of Prisoners notably states that:

Every prisoner on admission shall be provided with written information about the regulations governing the treatment of prisoners of his category [...] to adapt himself to the life of the institution.

This would ensure that prisoners are not treated like "a dog in a kennel" where they are left to own devices. Although it is argued that being sent to prison is a punishment, it is the withholding of one's liberty which is core aspect of the punishment. Therefore, a prison sentence should not encourage secondary punishments by disregarding difficulties being faced by those behind bars (Adams, 1992). Within such a sensitive transition as prison adjustment, prison officer support is vital since their responses to the prisoners' needs affect the overall adjustment period, and their general attitude to the prison sentence (Acevedo \& Bakken, 2003).

\section{1 'The Green Book'.}

As part of their 'induction' process, prisoners at CCF are purportedly given a handbook. Referred to quite bluntly as 'il-ktieb l-ahdar' ('the green book'), this pamphlet is The Prisoner's Handbook. It is a 10-page reference book, with 5 pages written in Maltese and the other 5 pages translated to English. The book should provide the new prisoner all the necessary information about the prison regimes, and the dos and don'ts of the facility. However, most prisoners said that they were not given a copy of the handbook.

As narrated by the prisoners:

Matthias: They had to give me a book, about regulations and the likes but nobody gave it to me. Everything was done by observation. Like a chicken.

Ben: They didn't give me anything. I got the book after I had been in here for a good year and a half *laughs*, because there was [nickname] and he fought for it here, he wanted the old one though. Because 
that was a better version, before they fixed it.

Prisons who were given a copy of the book stressed that they did not find it helpful anyway. One prisoner explicitly said he could not make sense of it and another stated that all the book alleges is based in 'fiction', as none of it really happens anyway.

Manuel: They did tell me something, and also gave me a book. But it is full of lies because things don't happen. Everything is down to preferences - for example because I know someone, l'll get something.

Henry: They have given me a book, but I just discarded it as I cannot read.

Paul: I was given a small book but it wasn't of any help and it wasn't organised at all. The other prisoners were of more help to me.

This lack of support and direction was further illustrated when several inmates did not even find the book important enough to mention. The author acquired a copy of this book, and regrettably, the reason why the prisoners did not find it effective, and pragmatic became very understandable. The book is printed on glossy paper in a very small font. As stated by the prisoners, this book does not take into consideration any learning disabilities, or the fact that most prisoners do not have a high level of education. The wording and sentence structure used in the handbook is complex. Offering a one-size fits all handbook, which is fundamentally aimed at those with a higher literacy level gives credence to the prisoners' statements that the prison does not cater for the educational differences the prisoners might have. Furthermore, it does not even cater for the weakest, therefore those who need help the most are deprived of basic information and assistance due to their inability to collect the necessary information about the prison regime.

It is concerning to see the extent of the lack of support, even when it comes to equally providing all prisoners with the same resources. Moreover, equity did not seem to matter within CCF, as prisoners who could not read were still expected to get to know the regime through this pamphlet. More concerningly, officers did not seem to know if prisoners needed further assistance in terms of literacy and learning difficulties, even though the general prisoner comes from a lower educational background. Nor did they seem inclined to inquire. Without the individual needs-based knowledge, the officers will not provide custom made support to individual needs. This person-centred approach (Bosick et. al., 2015), seemed to be missing within the CCF environment, which meant that services were not tailored towards the individuals, but focused solely on what is available at the time. Prisoners' narratives around this 'green book' sets the scene for what they will experience later during their prison sentence. However, the fact that no initial sentence plan was conducted plays a significant a role as to why the prison could not tailor to prisoners' needs, since no information and assessment on which to plan treatment and interventions was available.

\subsection{Reluctance to approach officers.}


Even though prisoners did not have the necessary information needed to make sense of their surroundings, or for those who were accustomed to the environment to move forward towards rehabilitation, they were still reluctant to approach officers for fear of being mocked. Prisoners claimed that prison officers were actively counterproductive to any form to rehabilitation and not susceptible to being approached:

Eman: I have nowhere to go when I'm out, but I won't ask them because they'll take the piss right in my face.

Alfred: The officer is so fed up, more than I am, that he must berate someone. Even if I say, 'thank you', they think I am taking the piss.

Liebling (2004) notes that the way authority is exercised has a profound impact on the totality of the prison experience, both in terms of order within the prison, but also the overall moral quality and legitimacy of the institution. Prisoners in CCF felt that authority was imposed on them in a very mocking, and sarcastic manner, which suggests that officers tend to resort to on coercion and fear, using tactics found in cultures of violence (Scraton et. al., 1991). Prisoners felt that they would rather risk homeless when released than face up to the officers' sarcastic and hurtful comments. Within such cultures, obedience is secured through threat of, or actual use of, legal or illegal sanctions, for example isolation or neglect, both aspects which are clear from the prisoners' narratives. This use of force goes against cultures of support, and as argued by Kaufmann (1988), is not just inefficient but also counterproductive.

Prisoners pointed to the absence of help, and harrowingly stated that the officers are only there because it is their job:

Oliver: Listen, the officer is only here as a job, he does his work by spending the day in here, but he doesn't do anything. He won't help you. Maybe one out of fifty you'll find someone who's good, who would try to enlighten me.

Gorg: There is no help whatsoever here. I tell them [officers] - you are just here to get paid. There is no help. This attitude is ridiculous [...] [They're here] just for the number, no help at all. There are some good officers who respect you, but they cannot do much else.

Manuel: No [the officers do not help]. Do you know what the role of the officers here is? Just to open and close doors. There is no interaction. The majority of them, they look down on you. They have to make it clear that they're the officer and you're the prisoner.

Prisoners have clearly argued that the basic role of the prison officer, that of 'opening and closing doors' is the sole purpose. Prisoners do not see officers as being more than "street-level bureaucrats" (Lipsky, 1980), responsible only for policy implementation without interaction or care. Scott (2006) alleges that most prison officers do not join the service to support people. Rather, the reasons are more punitive and disciplinary, focusing on security, supervision, and policing, where personal authority is dominating. When officers prioritise prison security within the prison regimes, a constant monitoring to maintain static and 
dynamic security is deemed to be essential (Arnold, 2016; Liebling, 2011). Therefore, time from other more rehabilitative and 'caring' aspects of their role is substantially reduced.

This perception posed by the prisoners has been reflected by Einat and Suliman (2021) who concluded that a change within prison officer personality was a decline in conscientiousness. Prison officers had a reduced tendency to channel urges to functional operations, therefore, the ability to make plans, develop tactics and strategies and then executing them consistently was absent leading to reduced work ethics, success, and persistence (Lambert et.al., 2018). This is what the prisoners at CCF are experiencing from the officers. Rather than officers who strive for solutions, in terms of rehabilitation and the daily struggles, prisoners are faced with reluctant officers, who are there 'for the number'.

Despite seemingly withdrawing from their duties, prisoners state that the officers expect them to see their officer status as being superior, recognise and accept this, and treat them with more respect (Sykes \& Brent, 1983), a form of prisoner deference which seems to be vital for prison officer self-esteem (Carter, 1995). However, prisoners also state that this respect is not given a two-way stream; officers expect reverence but would not show respect back.

This leads to inmates expressing indifferent to the officers and they do not see them as authority figures with a duty of care:

Mark: *shrugs* They don't affect me at all. He's a person like me, just wearing a uniform. I don't give him the time of day. I call him 'sir' because I have to. Otherwise...

Hubert: Eh, to be honest? I'Il tell you I think they're overrated you know. I truly think - and don't take offence to that - but they're overrated.

Within the same way that policing literature would reiterate the crucial element of support between the police and community to increase effectiveness, so too should penological literature emphasise such relationships between prison staff and prisoners. This relationship is a steppingstone to achieving legitimacy (Hinds \& Murphy, 2007) rather than the indifference experience by prisoners.

\subsection{A dim light}

In contrast, a small minority of prisoners commented that some officers do try to make the prison sentence bearable, by attempting to show some of support and kindness. However, this is tempered by them being a small number and limited in what they can do:

Laurence: There are many officers... I cannot complain, they try to help with the least they can, but all he can do is try to give you courage, telling you that life goes on and that this sentence is over one day, they cannot really give you more than that.

This feeling of hopelessness in terms what prison offers can do is also felt by staff. As stated by the prisoners, and mirrored by the officers, some officers did genuinely want a make a different in the lives of prisoners, however there were many hurdles to jump, not least management itself. Crawley (2006) states 
that many times prison staff may feel that they are inadequate, both in practise and numbers, to offer successful rehabilitation, even though they also often feel that prisoners are not interested, and they feel at a loss as to how to make positive changes. This can be seen to mirror data collected by the Howard League for Penal Reform (2017), where prison officers in the UK stated that they felt they had a lack of decision-making powers, leaving them 'at rock bottom' with very low morale. Moreover, comparatively, this seems to be a common feeling within the prison officer role: despite the very high level of education and training offered to prison staff in Sweden, this lack of autonomy in decision making could also be felt, especially in terms of rehabilitation-centred decisions (Vereycken \& Ramioul, 2018).

Perhaps due to this feeling of helplessness which would result to staff feeling unmotivated and able to support prisoners, or due to a general lack of awareness and comprehension of the importance of this support in terms of desistance, only two prisoners stated that they found some degrees of support from the prison system, and stated that they were assisted with making some form of plan for their release and beyond:

Matt: More than anything, the prison has helped me move the pieces of the jigsaw puzzle that is my life together. It has helped me learn how to motivate myself since I had a lot of time on my hands.

Henry: Now I have one [a plan], till some time ago I didn't. Ever since I spoke to them, things took a different turn, I'm coming off the medicine [methadone] and going to Division 7, I'm going to the [drug] programme and come back to Division 7. I could be out before because I've been here for longer than two years.

\subsection{Categorising and trying to understand officers.}

Throughout the interview process, prisoners grouped prison officers into two seemingly natural categories - 'I-antiki' (the 'old ones', i.e., those who have been part of the prison service for a long time) and il-godda (the newer recruits). However, there were mixed feelings regarding if it was the 'older' ('I-antiki') officers or the new recruits who offered the most help and support. The general hypothesis was that the longer an officer has been exposed to the harsh prison conditions, the less empathy and aptitude to help they showed. In fact, prisoners assert that the officers, those who have been working at the prison the longest, have the worst attitude, to the extent that this negativity and empathy shown by these officers is passed on to any new recruits:

Philip: Officers, especially the 'old' ones, they have a very bad attitude. Then what happens? The 'old' ones ruin the new ones.

This mirrors conclusions on studies on burnout and prison staff, for example Gray-Stanley and Muramatsu (2011), who, among others, state that those officers who feel that they have no autonomy might be at a greater risk for burnout. Adding several years of occupational and environmental stressors to their daily lives would result in a heightened stress level (Andrews \& Bonta, 2010). Therefore, the prisoners' rationale into the 'bad attitude' of the prisoner officers who have been part of the prison service longest could be explained by severe stress and burnout. 
At the other end of the career spectrum, the minority of prisoners believed that new prison officers had little to offer, not least because of their demeanour:

Charlie: The new recruits have practically no idea... if it weren't for the fact that their hands are where they are, and their feet are where they are, they wouldn't even walk and move. The way they talk is uneducated 'hey cow, hey dickhead,' their swearing never ceases, 24 hours. I do not want to sound harsh, but they can drop dead.

Vincent: The new ones are the worst because they try to show that they are... superior, you know? There are some 21, 20, 18-year-olds... and you need to call him 'sir'. And he will correct you if you don't call him so!

During the interview and unprompted, prisoners tried to understand why prison officers did not seem inclined to help and support them. Respondents stated that high level training and education is absent for officers:

Martin: The officers didn't have the proper training to handle frustration. It usually ended up 'fuck you then' and people running everywhere.

Mark: I don't really think they get the real training of being an officer. I say training but I mean they're not informed enough. The chain of command is not there.

Malcolm: I notice that those who do not show respect do not do it on purpose, they do it without a thought because they are uneducated people. Because there are many like that here. There are some who goddammit cannot even read and write properly. When you lack education, my attitude is like someone from the fields. Stupid we'd call him.

\subsection{Support only for the 'right' people.}

Prisoners thought that receiving support was conditional on 'knowing the right people', including nepotism and favours. These responses were couched in terms of having the right contacts, with some framing this as institutionalised corruption:

Paul: Nobody knows you and no one gives a shit about you. Unless you know some people.

John: I believe that all the programmes that exist are gimmicks, offered only to those they want to offer them to because in here it's who you are and who you know here really.

Vincent: Corruption is considerable here, big big big. For example, it would be my turn for a programme, there would be someone who knows someone, and he goes first. Only ministers can help you.

Interestingly however, some prisoners saw no shame in 'knowing someone' or seeing nepotism as a feature of prison life to be exploited: 
Aaron: I went in and had already known people who work at the prison and they told me how it works. In fact, as soon as I went in, they are supposed to lock you in so that the doctor can visit the day after and one [officer] and came and told me 'come for coffee'. I already knew the prison system and all, for the first six months you're supposed to stay in the division and after 15 days I was working in prison.

Moreover, prisoners insisted that the officers were more concerned with their own agendas then supporting the prisoners and giving them time and assistance. They narrate that they get away with it because they 'know the right people':

Mark: A senior officer told [prisoner A] to beat up [prisoner B], because [prisoner B] stole his mother's handbag. Nothing happened to the officer. Obviously.

Saviour: Nobody helps here, it's too political. There is no coordination or cooperation between anyone, even to the detriment of the prisoners.

Even though the practice of "peacekeeping" (Liebling \& Price, 2002: 2), whereby officers utilise their power though various negotiations, such as in this case, giving extra privileges, rewards, and personal authority to 'buy' compliance, is very clear within CCF, officers are operating above the rule of law which undermines the importance of fair treatment. However, within the Maltese prison, it is not just a case of compliance. A clear aura of corruption is felt, where privileges are reserved for those who are 'with us' (maghna: 'in our club'). This exclusive club is joined by being a strong supporter of a particular political party, at time of writing the Labour government, or by knowing the right people in power. Just as privileges can be awarded, officers, as "caretakers of punishment" could resort to the other end of the spectrum, were extra-legal discretionary and informal punishments are given (Scott, 2006). A foreign national prisoner explicitly stated that is can take a very serious take at CCF:

Jan: $X$, the guy responsible for prison records, hinders people's lives. He always say he make a mistake, [inputted the] wrong release date, he always get away with it.

However, as much as prisoners' support and assistance was conditional to their political affiliation, so to was it a case for officers, as illustrated by the prisoners. An ex-prisoner, Daniel Holmes, stated in his memoire that when in 2013 the Labour government was elected to power on the island, there was an overhaul of prison officers at CCF. Nationalist party supporters were quickly replaced by those who voted the Labour government in. Therefore, the predominant 'otherness' within CCF is profound.

This is a rather curious concept since officers and prisoners have similar socioeconomic background. Gellner (1983) states that even though national identity is socially constructed, similarities like ethnicity, language, background, and religion allow for greater cohesion between groups of people. However, Malta's colonial mentality has not been washed off by the sea of time, maybe because even after its independence, Malta has always relied on the British, especially financially and later in 2004 on the European Union, as a new member state. However, politically, the island demanded absolute independence and treated anyone who was an outsider as potential colonial powers (Smith, 2008). This 
suggests that the Maltese population feels vulnerable, not quite comfortable with the changes that independence brought on them. Therefore, there is an over-reliance on entities and organisations deemed to be stronger, as well as security. Instead of the Maltese people having a healthy national identity, the loyalty lies within political parties and the protection offered to individuals.

Maltese culture is deeply entrenched in politics, so much so that political loyalties are rooted in both social and family contexts (Hirczy, 1995). Through this reverence, favours are granted in a very Biblical manner, favours which some might refer to as comparable to a Faustian pact. Malta is as Catholic as it is political, yet such an irony is lost on the locals. The politics there, however, is not the kind one would expect from a European Country and member of the European Union; and it has been labelled as a 'country to watch'by Transparency International (2019), where 'corruption is undermining the rule of law' (Transparency International, 2019a), a practice which is evident within the institution meant to correct such behaviours.

[1] In CFA, only prisoners who are housed on Division 7, at time of data collection, were allowed any prison leave.

\section{Conclusion And Recommendations}

Most prisoners pointed to a lack of support from uniformed prison staff at the point-of-entry to prison, with many thinking they were treated with indifference or contempt; and where there was support, this came in the form of what might be called 'political patronage' (or corruption) rather than meeting the prisoners' right of access to information and sentence planning. The uniformed officer was not seen by prisoners in a flattering light. Crewe (2012) rightly observes that uniformed staff find themselves in the middle of the prison hierarchy, cruelly caught between management and prisoners, leaving them unloved by prisoners and unsupported by management. In this situation, the likelihood is that mistrust and suspicion and lack of helpfulness will consolidate and deepen. The problem may not lie in the supposed immoral character of the prisoner or the perceived brutishness of the prison officer, but in the absence of sound management - with top-down, enabling mechanisms that ensure safe fulfilling roles for prison staff, together with a proper regard for prisoners and meeting their needs for rehabilitation, as required by law. This lack of management at CCF has been reported by the European Committee for the Prevention of Torture and Inhuman or Degrading Treatment or Punishment (CPT: 28) in their 2015 report, stating that 'the CPT's delegation once again observed a lack of established management and the absence of a clear operational strategy for CCF.'

Despite research stressing that importance of support on the desistance journey, a good number of prisoners felt that motivation and assistance is lacking from the prison and prison staff. Moreover, the prison officers do not seem to encourage the prisoners to get the necessary help they need. As Murdock (2020) states: 'Anything goes in Malta, from murder to money laundering to drink driving. As long as you're connected to the right people, you will never be held accountable.' This impeccably sums up the prison situation on the island. Nobody seems to be held accountable for the dire conditions in CCF, or for the lack of support and solid rehabilitative programmes. 
The results presented in this paper have illustrated that a certain change is vital within the prison and its administration for prisoners to feel more supported within their sentence. This support will give them a better chance at 'making good', therefore decreasing re-offending, recidivism, and potential victims.

When a prisoner refers to the prison as 'Monty Python's Flying Circus', it is evident that a change is needed.

The author recommends that:

1.More information should be provided to prisoners, especially during their induction period This could take the form of one-to-one information sessions, or through a practice akin to an induction unit. An induction unit would provide two strands of information sources - official information provided by prison staff, and peer support. This would be in adherence to Rule 30 of the European Prison Rules (Council of Europe, 2006) which stresses the importance of all information pertaining to rights and duties are always communicated to all prisoners. This would alleviate some of the uncertainties and extreme stress which results from the transition from freedom to captivity.

2.Within this induction unit a sentence plan should be drafted for each prisoner. Preliminary tests (focusing on education, mental health, and criminogenic needs) should be offered to the prisoner to determine their individual needs. A requirement for this induction is found within the Laws of Malta. Article 11(a) of the Prison Regulations Act (1995)[1] states that soon after admission, a report on the background of the prisoner should be compiled. Article 11(b) requires a 'suitable training programme in preparation for ultimate release' to be drawn up for prisoners with longer sentences; and this should be done jointly between prisoners and officials. The introduction of the Restorative Justice Act[2] in 2012 brought sentence and care planning to the fore. However, at the time of data collection this was deemed to be ineffective, since the number of staff recruited was modest at best. This was also commented on by the CPT delegation on their visit to Malta in 2015 (Council of Europe, 2016), who noted that these plans were only compiled for prisoners applying for parole. These prisoners had no active involvement in their sentence plan, and a copy of this plan was not given to the prisoners. The CPT was due to revisit Malta in 2020, however this has not happened. However, the importance of having a clear sentence plan, drafted with the prisoner cannot be stressed enough.

3.Offering a simple and structured handbook for prisoners is vital. The Prison Reform Trust, a charity in England and Wales, offer some exceptional information sheets and handbooks aimed at prisoners on several different circumstances they might be faced with. They are simple and concise to read, within a very organised framework. Rather than printed on glossy paper with a very small print, a prison handbook should be graphic and written in large print, in simple language. It should give basic information, for example what a normal day in prison looks like, as well as information about education programmes and other activities the prisoners can participate in. More importantly, it offers the prisoner advice on who to talk to should they need further information. In this way, the prisoner is never left stranded. 
4.More staff training is essential. This should move away from the sole aspect of security and into rehabilitation. Currently, the official job description of a correctional officer in Malta does not mention any form of positive or active relationship between officer and prisoner. Instead, terms such as 'guarding', 'inspecting', 'observing' and 'escorting' are used (Ministry of Home Affairs, 2017). This does not indicate the two-way communication channel between staff and prisoners necessary to allow for a high level of cooperation and a successful sentence plan. It does not take account of the 'caring' role officers hold, which is achieved through dialogue between staff and prisoners. It could be argued that if this positive relationship is not even mentioned on basic a role description, then there is little hope that it will be a priority in training. If training is based on the above security-focused characteristics, then the vicious circle of security rather than communication and rehabilitation is put in force. Therefore, a core change needs to be present within the role of prison officers, and this needs to be reflected from the introduction and assessment of the role itself.

5.Improvements in the general prison building is fundamental. The generalised indictment of prison staff needs to be set in the context of a dilapidated penal estate, with impoverished living conditions for prisoners and unsavoury working conditions for staff. This has two-fold negative repercussions, potentially adding to the various stressors already highlighted within a prison environment. The CPT (Council of Europe 2016, p. 31) report on their visit to the prison highlights this decrepit environment. The report addresses 'generally poor living conditions for the prisoner', with cells which were 'excessively hot with poorly functioning ventilation.' Furthermore, the 'extremely hot' exercise yards had no shelter to protect from sun or rain. Although the report identifies these misgivings in terms of prisoner accommodation, the fact that prison officers spend most of their day in these same conditions also deserves attention. Such terrible conditions cause concerns for the prison staff as well as the prisoners, since staff do not feel they are safe at their workplace, causing more stress and less inclination to help (Bartollas 1990). The Prison Reform International (2016) distinctly emphasise that the way prison staff perceive their working environment, as well as the way they are treated by managers and colleagues, has a drastic effect on how they treat prisoners, as well as the general atmosphere in the prison. Furthermore, it is a well-publicised fact that a positive working environment, especially in terms of lighting and temperature, would lead to higher productivity and more content staff (Gupta, Howard \& Zahiri, 2020).

[1] http://www.justiceservices.gov.mt/DownloadDocument.aspx?app=lom\&itemid=9674\&l=1 [2] http://www.justiceservices.gov.mt/DownloadDocument.aspx?app=lom\&itemid=11813\&l=1

\section{References}

Acevedo, K., \& Bakken, T. (2003) Women adjusting to prison. Journal of Health \& Social Policy, 17(4), 3760 .

Adams, K. (1992) Adjusting to prison life. In M. Tonry (Ed.) Crime and Justice: A Review of Research. University of Chicago Press. 
Akoensi, T.D., \& Tankebe, J. (2020) Prison officer self-legitimacy and support for rehabilitation in Ghana. Criminal Justice and Behavior, 47(1), 22-38.

Andrews, D.A., \& Bonta, J. (2010) Viewing offender assessment and rehabilitation through the lens of the risk-needs-responsivity model. In F. McNeil P. Raynor \& C. Trotter (Eds.), Offender Supervision: New Directions in Theory, Research and Practice. Willan Publishing.

Arnold, H. (2016) The prison officer. In: Y. Jewkes, B. Crewe \& J. Bennett (Eds.), Handbook on Prisons. (pp. 265-283). Routledge.

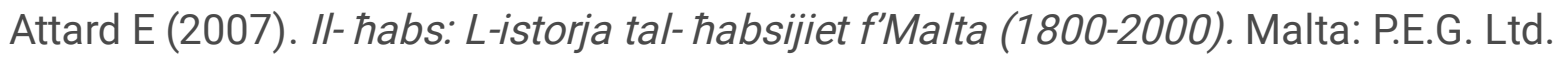

Baldacchino, G. (2012) Meeting the tests of time: Small states in the 21 st Century. Current Issues in Comparative Education, 15(1), 14-25.

Bartollas, C. (1990) The Prison. Disorder Personified. In J.W. Murphy \& J.E. Dison (Eds.), Are Prisons Any Better? Twenty Years of Correctional Reform. (pp. 11-22). Sage Publications,

Bastow, S. (2014) Transforming rehabilitation: Evolution not revolution. Criminal Justice Matters, 97(1), 10-11.

Bosick, S.J., Bersani, B.E., \& Farrington, D.P. (2015) Relating clusters of adolescent problems to adult criminal trajectories: a person-centered, prospective approach. Journal of Developmental and Life-Course Criminology, 1, 169-188.

Bottoms, A.E. (1995) The philosophy and politics of punishment and sentencing' in C. Clarkson \& R. Morgan (Eds.), The politics of sentencing reform. Clarendon Press.

Braggins, J., \& Talbot, J. (2005) Wings of Learning: the role of the prison officer in supporting prisoner education. The Centre for Crime and Justice Studies.

Braun, V. \& Clarke, V. (2008) Using thematic analysis in psychology. Qualitative Research in Psychology, 3(2): 77-101.

Calleja, C. (2020) AG will not give details on prison deaths inquiries. The inquiries are 'confidential in nature'. Times of Malta. https://timesofmalta.com/articles/view/ag-will-not-give-details-on-prison-deathsinquiries. 836246

Clark, R. (2012). Opportunity makes the thief. Really? And so what? Crime Science, 1(3), 1-9.

Clemmer, D. (1958). The Prison Community. Holt, Rinehart and Winston.

Council of Europe (2016) Report to the Maltese Government on the visit to Malta carried out by the European Committee for the Prevention of Torture and Inhuman or Degrading Treatment or Punishment (CPT) from 3 to 10 September 2015. Report, CPT, CPT/Inf (2016) 25. 
Council of Europe (2006). European Prison Rules. Council of Europe Publishing

Crawley, E. (2006). Doing Prison Work. The Public and Private Lives of Prison Officers. Willan Publishing

Crewe, B. (2012). The Prisoner Society. Power, Adaptation, and Social Life in an English prison. Oxford University Press.

Delia, J. (2021). 'It's our job to teach fear': prison notice signed by director revealed. Times of Malta.

Dean, K. \& Korobanova, D. (2017). Brief mental health screening of prison entrants: psychiatric history versus symptom screening for the prediction of in-prison outcomes. The Journal of Forensic Psychiatry \& Psychology, 1-12.

Earle, R. (2018). Being inside: Masculine imaginaries, prison interiors. In M. Maycock \& K. Hunt (Eds.), New perspectives on prison masculinities (pp. 43-64.) Palgrave.

Einat, T., \& Suliman, N. (2021). Prison changed me-and I just work there: Personality changes among prison officers. The Prison Journal, 101(2), 166-186.

Elisha, E., Shoham, E., Hasisi, B., \& Weisburd, D. (2017). For prisoners, "work works": Qualitative findings from an Israeli program. The Prison Journal, 97(3): 342-363.

Elliott, L. (2007). Security, without care: Challenges for restorative values in prison. Contemporary Justice Review: Issues in Criminal, Social, and Restorative Justice, 10(2), 193-208.

Engel, M. (2018). Malta: an island of secrets and lies. New Statesman.

https://www.newstatesman.com/world/europe/2018/02/malta-island-secrets-and-lies

Fedock, G. (2017) Women's psychological adjustment to prison: A review for future social work directions. Social Work Research, 41(1), 31-42.

Formosa Pace, J. (2014) Intergenerational continuity in offending: An approach to the phenomenon in the Maltese Islands. PhD Thesis, University of Huddersfield, UK.

Formosa, S. (2021) CCF. Prison and Prisoners. http://crimemalta.com/ccf.html.

Fowler, M., \& Bunck, J. (1996). What constitutes a sovereign state? Review of International Studies,, 22, 381-404.

Gellner, E.A. (1983) Nations and Nationalism. Blackwell.

Goffman, E. (1990). Asylums: Essays on the Social Situation of Mental Patients and Other Prisoners. New York: Doubleday. 
Gray-Stanley, J.A., \& Muramatsu, N. (2011). Work stress, burnout, and social and personal resources among direct care worker. Research in Developmental Disabilities, 32, 1065-1074.

Gupta, R., Howard, A., \& Zahiri, S. (2020). Investigating the relationship between indoor environment and workplace productivity in naturally and mechanically ventilated office environments. Building Services Engineering Research and Technology, 37(3), 280-304.

Hinds, L., \& Murphy, K. (2007). Public satisfaction with police: Using procedural justice to improve police legitimacy. The Australian and New Zealand Journal of Criminology, 40(1), 27-42.

Hirczy, W. (1995). Explaining near-universal turnout: The case of Malta. European Journal of Political Research, 27(2): 12-272.

Home Affairs (2020). Correctional Services Agency. Available at: https://homeaffairs.gov.mt/en/MHASDepartments/Correctional-Division/Pages/CCF.aspx (accessed 3 December 2020).

Homles, D. (2020). From a Cage, on a Rock, in a Puddle... A Memoire from Malta's Prison. Lovin' Malta. Kauffman, K. (1988) Prison Officers and Their World. Harvard University Press.

Lambert, E.G., Qureshi, H., Frank, J., Klahm, C., \& Smith, B. (2018). Job stress, job involvement, job satisfaction, and organizational commitment and their associations with job burnout among Indian police officers: A research note. Journal of Police and Criminal Psychology, 33(2), 85-99.

Lemaire, L. (2015). Malta: A new border of the European Union. The social construction of an islandprison. European Consortium for Political Research (ECPR) Conference, Montreal, Canada, 26-29 August 2015.

Liebling, A., Tait, S., Durie, L., Stiles, A., \& Harvey, J. (2005) An evaluation of the safer locals programme. Home Office.

Liebling, A. (2011) Distinctions and distinctiveness in the work of prison officers: Legitimacy and authority revisited. European Journal of Criminology, 8(6), 484-499.

Liebling, A., Price, D., \& Elliott, C. (1999) Appreciative inquiry and relationships in prison. Punishment and Society, 1(71): 71-98.

Liebling, A. (2004) Prisons and their moral performance. Clarendon Press.

Lipsky, M. (1980) Street-level bureaucracy: Dilemmas of the individual in public services. Russell Sage Foundation.

Mann, R. \& Fitzalan, H. (2018) What is a rehabilitative prison culture? Prison Service Journal, 235, 3-9. 
Martufi, A. (2018) The paths of offender rehabilitation and the European dimension of punishment: New challenges for an old ideal? Maastricht Journal of European and Comparative Law, 25(6), 672-688.

Maruna, S. \& LeBel, T. (2002) Welcome home-examining the reentry court concept from a strengths-based perspective. Western Criminology Review, 4(2), 91-107.

Maruna, S. (2001) Making Good. How Ex-Convicts Reform and Rebuild Their Lives. American Psychological Association.

Maycock, M., McGuckin, K., \& Morrison, K. (2020) 'We are "free range" prison officers', the experiences of Scottish Prison Service throughcare support officers working in custody and the community. Probation Journal, 67(4), 358-374.

Ministry for Home Affairs (2017). Position of Correctional Officer in the Department of Correctional Services in the Ministry for Home Affairs and National Security. https://homeaffairs.gov.mt/en/MHASInformation/Job\%200pportunities/Pages/2017/Position-of-Correctional-Officer-in-the-Department-ofCorrectional-Services-in-the-Ministry-for-Home-Affairs-and-National-S.aspx

Morris, N. (1995) The Contemporary Prison. 1965-Present. In N. Morris \& D. Rothman (Eds.), Oxford History of the Prison: The Practice of Punishment in Western Society (pp. 226-259). Oxford University Press.

Murdock, R. (2020). A corrupting island in a corrupting sea. The Shift.

Pierce, M., Hayhurst, K., Bird, S., Hickman, M., Seddon, T., Dunn, G., \& Millar, T. (2017). Insights into the link between drug use and criminality: Lifetime offending of criminally-active opiate users. Drug and Alcohol Dependence, 179, 309-316.

Reisi, M., \& Mesko, G. (2009) Procedural justice, legitimacy, and prisoner misconduct. Psychology, Crime and Law, 19(1): 41-59.

Ricciardelli, R., Idzikowski, M., \& Pratt, K. (2020) Lives saved: Correctional officers' experiences in the prevention of prisoner death by suicide. Incarceration, 1(2): 1-17.

Scott, D. (2006) The caretakers of punishment: prison officer personal authority and the rule of law. Prison Service Journal, 168, 14-19

Scott, D., \& Codd, H. (2010) Controversial Issues in Prison. Open University Press.

Scraton, P., Sim, J., \& Skidmore, P. (1991) Prisons Under Protest. Open University Press

Stevens, A. (2013) Offender Rehabilitation and Therapeutic Communities. Routledge 
Smith, S., (2008). Dependence and Independence: Malta and the End of Empire. Journal of Maltese History, 1(1): $33-47$.

Sparks, R., Bottoms, A.E., \& Hay, W., (1996) Prisons and the problem of order. Clarendon Press.

Steiner, B., \& Wooldredge, J. (2018). Prison officer legitimacy, their exercise of power, and inmate rule breaking. Criminology, 56(4), 750-779.

Sykes, G. (1958/2007) The Society of Captives. A Study of a Maximum Security Prison. Princeton University Press.

Sykes, R., \& Brent, E., (1983) Policing: a social behaviourist perspective. Rutgers University Press.

Tait, S. (2011). A typology of prison officer approaches to care. European Journal of Criminology, 8(6), 440-454.

Toch, H. (1977). Living in Prison: The Ecology of Survival. The Free Press.

Tracy, S. (2005). Locking up emotion: Moving beyond dissonance for understanding emotion labor discomfort. Communication Monograph, 72(3), 261-283.

Transparency International (2019a). CPI 2019: western Europe \& European Union. https://www.transparency.org/en/news/cpi-western-europe-and-eu.

United Nations. (1955). Standard Minimum Rules for the Treatment of Prisoners.

van Zyl Smit, D., \& Snacken, S. (2009) Principles of European prison law and policy. Oxford University Press.

Vereycken, Y., \& Ramioul, M., (2018) Quality employment and quality public services in prisons. KU Leuven.

World Prison Brief (2021). Malta. https://www.prisonstudies.org/country/malta.

Worldometer (n.d.). Malta Population. https://www.worldometers.info/world-population/maltapopulation/.

Worley, R., Barua Worley, V., \& Lambert, E.G. (2021). Deepening the guard-inmate divide: An exploratory analysis of the relationship between staff-inmate boundary violations and officer attitudes regarding the mistreatment of prisoners. Deviant Behaviour, 42(4), 503-517.

Zimmer, L. (1986). Women guarding men. University of Chicago Press. 